\title{
Immigrant Associations and Co-development Policies. Among the Opportunities for Strengthening and the Risks of Cooptation in the Case of Valencia Region (Spain)
}

\author{
Joan Lacomba, Alejandra Boni, Alexis Cloquell y Carlos \\ Soledad.
}

Final version of a paper which was published in 2014 in Voluntas, Septiembre, 1-12. The final publication is available at link: http://link.springer.com/article/10.1007/s11266-014-9491-9

\section{Abstract}

The implementation of policies that have sought to involve immigrant associations in the development of their countries of origin, under the name of co- development, was a novelty in Spain during the last decade. This new model of development cooperation carried out by the migrants themselves has not only generated new opportunities for its associations, but also significant risks, especially in the field of decentralized cooperation driven by autonomous communities. In this article, we present the specific case of the Valencian Community, where the co- development reached a considerable degree of implementation between 2006 and 2012. Through the analysis of Valencian co-development policies, it is possible to see how immigrant associations have actually occupied a secondary place in the new cooperation schemes against the NGO Development, while many have abandoned their protest to focus on projects and proposals for welfare activities.

\section{Resumen}

La implementación de políticas que han tratado de implicar a asoci- aciones inmigrantes en el desarrollo de sus países de origen, bajo el nombre de codesarrollo, fue una novedad en España durante la pasada década. Este nuevo modelo de 
cooperación al desarrollo llevado a cabo por los propios migrantes ha generado nuevas oportunidades para sus asociaciones, pero también riesgos sig- nificativos, especialmente en el campo de la cooperación descentralizada impulsada por las comunidades autónomas. En el presente artículo, presentamos el caso específico de la Comunidad Valenciana, donde el codesarrollo alcanzó un consider- able grado de implementación entre 2006 y 2012. Mediante el análisis de las políticas de codesarrollo valencianas, es posible ver cómo las asociaciones de in- migrantes han ocupado realmente un lugar secundario en los nuevos planes de cooperación contra el Desarrollo de ONG, mientras que muchas han abandonado su protesta para centrarse en proyectos y propuestas de actividades de bienestar.

\section{Keywords}

Associations · NGOs · Immigrants · Co-development policies

\section{Introduction}

The term co-development has figured prominently in migration and development cooperation in Spain during the first decade of this century. After a failed first attempt in 2000, with the design of an ambitious Global Program Regulation and Coordination of Foreigners and Immigration in Spain (GRECO Plan), which was never implemented, in 2005 the Director of the Cooperation Plan Spanish retook the co-development as one of its main lines of action, and in 2007 the Strategic Plan for Citizenship and Integration did the same. At the same time, different Spanish Autonomous Communities have included references to the co-development in their own plans and have launched specific funding calls for codevelopment projects. In an institutional context in which it has sought to promote co-development from government policies, the results of this new route (which has often been presented as a new form of development cooperation) are still difficult to assess, but have been accompanied by numerous reviews.

In this article, we focus on those reviews which emphasize the 
connection of co- development with the demobilization of the claims of migrants and the momentum of certain useful organizations for this purpose. The risks identified in other contexts regarding the incorporation of migrants into new transnational development schemes (e.g., the Mexican case detailed by Fox, Escala (2005), Goldring or Moctezuma) are also noticeable in the Spanish experience, and especially in the case of the Autonomous Valencian Community, to which we devote much of our work. The political construction of a new field of co-development has enabled articulate new forms of relationships between the different actors involved (government, non-governmental development organizations and immigrant associ- ations), while promoting the emergence of new organizational profiles (entities oriented, since their early beginnings, to co-development for migrants and nonmigrants) or the creation of new platforms (the case of the Federation of the Co- Development and International Cooperation in the Valencian Community, herein- after FEDACOD). Similarly, the official opening of new methods for co- development funding has put many of these organizations in the search for resources by presenting projects. However, upon understanding that participation in the new field could mean a loss of independence and a loss of the ability to pressure their advocacy work and defend the rights of migrants, as we illustrate in this article, some immigrant associations, and NGO Developments (hereinafter NGOs), have decided to stay out of this new field or have entered into processes of internal debate. Also, in a context in which migrants have not secured full citizenship, organizations have opted for codevelopment, and have seen an opportunity to become visible by accessing certain areas of representation and dialog, while the most critical organizations have seen in this invitation an attempt by the administration to weaken their demands for greater rights, if not a strategy of political co-optation. Therefore, the classic work of Albert Hirschman (1977) becomes relevant for our analysis, in terms of the three scenarios for organizations in their relationships with the political power: the possible break (exit), the claim (voice) and submission (loyalty). As we will see later, the three strategies were present in varying degrees between immigrant organizations and NGDOs, in their positioning of co-development policies promoted by the institutions.

The first part of the article is devoted to reviewing some of the studies that have analyzed the role of migrant organizations in other 
contexts, particularly based on their engagement in development programs and their relationships with other actors. Second, we try to do a reconstruction of how it would have gestated a specific field of co-development in Spain. Third, we delve into the particular context of the Valencian Community, where many of the dynamics that have accompanied the political construction of a codevelopment field have become particularly visible. Finally, we detail the opportunities and risks that co-development policies have generated for immigrant associations, making a general assessment of the changes they have experienced, including established relationships with NGOs themselves, more often in terms of dependence on them than the searched associative strengthening. To illustrate these issues we handle field data obtained by questionnaires and interviews from two investigations conducted during 2010 and 2011 in the territory of the Valencian Community.

\section{Migrant Organizations, Development and Public Policies}

The revival of the debate on the link between migration and development in the first decade of the century has put migrant organizations under spotlight, seen as key agents in the operationalization of the new political schemes around this area, an issue that has not been without controversy. The attempt to conceive migrants and their organizations (and processes responsible for promoting development in their countries of origin) has been criticized by several authors, who argue rather that migrants cannot alone constitute a development agent, while this proposition results in "unsustainable level processes reaching social transformation” (Delgado and Márquez, 2007, p. 22).

However, the idea that migration can play a positive role in the development if framed within public policies that help to channel their effects properly-we talk here, especially in the first instance, about remittances from migrants-has gained remarkable strength, and has been accompanied by the exaltation of the migrant organized as an actor in this new scenario, associated in this task with large international organizations, states and even the private sector. Inside this new triangulation in the transnational social space between community, market and state spoken of by Faist (2005), 
migrant organizations have gained significant value for both the states of origin and receiving states. For the former, the always complex relationship with diaspora has evolved toward normalization of ties and attempts to attract them toward programs that ensure their involvement, to varying degrees, in development (for example the more travel 3X1 Program in Mexico, or the latest in El Salvador, Colombia or Ecuador). For the latter, cases have varied considerably, especially in a number of European countries, including Spain, as we will see later, and a new agent development cooperation has been implemented in regions which now also receive the migrants themselves. In this sense, for both states of origin and receiving states, the possibility of structuring the participation of migrants across their organizations has proved to be a catalyst for new officers' devices and in turn has generated new relationships with transnational migrants as development actors. However, these new relationships raise the question about the place that has been attributed to migrant organizations and, above all, the changes that have occurred in the organizations to adjust to new schemes.

In the literature on transnational migrant organizations the analysis of these organizations as well as their practices has been privileged, but the impact of the relationship with government agencies that guide their actions has barely been investigated. Similarly, most studies addressing the relationship of states' organized diasporas have investigated from the point of view of the countries of origin rather than the receiving states. Many states have maintained policies or programs designed to try to influence behavior, including political behavior of their citizens abroad (see the case of Mexico ${ }^{1}$ ), but only a few states have developed policies to influence organizational behavior-sometimes also with policyof the migrants settled in their territory.

Faist's review on the role of transnational migrants as agents of development indicates how different states-including some European and international orga- nizations-have recently turned his gaze to migrant associations to become "diasporic actors" (2008, p. 26). This renewed interest in his judgment contains important background issues such as the tension between the role

\footnotetext{
${ }^{1}$ The case of Mexico has been one of the most reviewed into the scientific literature, with a long list of works like Gonzalez-Gutierrez (2006), Goldring (2002) or Guanizo (1998).
} 
of transnational migrants as agents of development and political interests, and control of the states of origin and destination (2008, p. 36). Another key study within the analysis of transnational immigrant organizations-the Portes, Escobar and Walton reportdiscusses the growing initiatives by governments seeking to channel the activities of migrants (remittances, investments and philanthropic contributions) or simply to ensure their loyalty. Portes and his collaborators posit then that "according to the scope and material resources allocated by governments as well as the purposes for which they are used, immigrant organizations can accept and adopt the official line, stay independent of it or actively resist it as an unwanted interference" (2006, p. 14). Meanwhile, Fox and Gois, from the Mexican case, referring to the role of migrant civil society, warn of the risks that participation in official schemes can entail for the organizations themselves, either by integration in the same project (concentration in a few states where migrant organizations have a direct influence on policy), state governments or by the exclusion of those organizations that are more critical to the development agenda (for example, those immigrant associations campaigning against the violation of human rights in Mexico) or who are in favor of broader development policies, and may well be excluded from the program One by Three (2010, p. 115). On this issue Goldring goes even further, noting the Mexican state's attempts to establish a clientele and coopting relationship with its diaspora abroad, through its policies and programs for migrant organizations (2002, p. 78).

What we can see through the studies cited is how conflicts between community and state in the terminology of Faist can arise when migrant organizations have different objectives to those of government agencies that promote government programs, including different interpretations of participation within them. To Faist, this new scenario is a source of friction between the different actors involved, but also constitutes what he calls a space of opportunity, while linking development policies_-including migration and border policies-especially in the European context, meaning a possibility that groups and transnational partnerships receive prominence and reach some power. So, because these public policies do not just focus on the returning of migrants as a way to promote development, but also in promoting transnational networks, migrants and their organizations would be willing to assume a growing role (2005, p. 30). 
In the case that we are studying, first and foremost, the relations of the Spanish government agencies, and above all the relations of the sub-national agencies (regional and local) with immigrant associations, the guidelines mentioned above are particularly appropriate. We try to show that the emergence of a formal codevelopment field, driven from official authorities, would have had, as one of its achievements, a greater public visibility of immigrant associations, but the price in many of the cases is a loss of autonomy in the debate on the development agenda and a shift toward actions based solely on projects.

\section{The Emergence and Transformation of Co-development in Spain}

In 2000 the concept of co-development made its first official appearance in Spain through the GRECO Plan, and has since been under intense discussion. Today, the discussion is still open and many still debate over whether the co-development is a tool, a specific methodology, a perspective, a form of development cooperation, or a management tool. Amid the lack of consensus, some authors argue that it is a hybrid concept, which encompasses the phenomenon of migration and development cooperation and is positively linking migration and development, starting from the premise that migration generates power or development (Giménez 2004). Cortés (2006) points out in turn that it is a polysemic concept, as it is understood and manipulated by different actors (international organizations, states from the central government, regional/regional or local NGOs, immigrant associations, immigrants and their families, etc.) in a different and concerned way. There is no chance here to present and discuss the different meanings attributed to the co-development to exceed the scope of this work; rather, what interests us here is to trace what might be the main features of the Spanish co-development model and its evolution in the short period of just 10 years.

For the first question, the very fact that co-development in Spain has built momentum from the field of development cooperation from their own migration policy has mostly promoted the ways of development cooperation whose purpose is aimed at fighting poverty and, more specifically, lowering socioeconomic 
differences between countries of origin, transit and destination of migration by promoting human development. This approach would be accompanied by the conception of migrants as agents of development and co-starred in the process of co-development with a wide network of stakeholders, both public and private, located at origin and destination. According to Cortés and San Martin (2007), the most significant contribution to Spanish co-development would be to simply build a "model to three," which would have the actors represent the migrants themselves through their associations, public administrations and NGOs. Networking between the three parties and the formulation of action at source under this scheme would be the main components that accompany the development of codevelopment in Spain.

As for evolution, co-development has experienced a rapid and intense course, which has happened in little more than 10 years, first involving the distrust of immigrant associations and also many NGOs, a key characteristic of the decade (when the codevelopment was seen as an instrument to facilitate the return of migrants, or when the NGOs saw in immigrant associations too a potential competitor) to a stage in the middle of the decade in which many of the immigrant associations and NGOs themselves agreed to participate in the implementation of projects or platforms prompted, without renouncing co-development, while also keeping a vigilant eye on it (e.g., the creation in 2007 of the Network of Immigrant Associations by co-development, REDCO). Finally, when the co-development was said to have reached its mature stage, reviews seemed to have reduced their intensity and both public institutions and civil society organizations in the co-development saw an opportunity to influence the development from different schemes through the cooperation of the classical development. The deep economic crisis in Spain right now has led to a significant reduction in public budgets and the difficulties faced by the organizations themselves have significantly lowered social expectations, to the point of precipitating discourse on the future of co-development. ${ }^{2}$

\footnotetext{
${ }^{2}$ In fact most of the official calls out that have been created to specifically support projects of co- development have disappeared. This is the case of the Valencian Community where the last call out was publicized in 2012.
} 
Unable to say yet what the extent of the effect of an ongoing crisis on the co- development field will be, we do want to highlight here that some of the discussions over the years have been on the basis of distance from various immigrant associations and NGOs regarding the co-development in order to help better understand the case we will present later.

First, a large number of authors have seen co-development as something propelled by administrations: the top security concerns and the issue of returning immigrants (Gómez, 2008), both inside and outside of Spain. For example, in France, reviews have also been frequent (France has the same origin of co- development as a concept and state policy as Spain) and, as Bayart pointed out, although co-developments were originally intended to involve civil society and migrants with official development assistance, it would be progressively trans- formed in what he called an antimigration device (Bayart 2007, p. 26). Daum delves further into this matter, and highlights the ambiguity between the development of countries of origin and management of migration flows, and questions for whom the official co-development seems to be more oriented to organize the cooperation of countries of origin in the control of immigration with a repressive vocation (Daum 2008, p. 58).

In Spain, the first formulations contained in the GRECO Plan, taking as a reference the French co-development model and the guidelines for the creation of an area of freedom, security and justice in the European Union (Treaty of Amsterdam Treaty Tampere), had a fairly close proximity with strictly secured approaches (Lacomba and Boni 2008). With the entry into government of the Spanish Socialist Party in 2004, the GRECO Plan was repealed, but it had already taken root. From this point the co-development began acquiring a special role in state development cooperation and gradually separated from the safety objectives. References to co- development first appeared in a Director of the Spanish Cooperation, the 2005-2008 Plan, and in the respective Annual Plans for International Cooperation (PACI).

Second, note that since the sub-national authorities' involvement, this dichotomy between co-development linked to security and codevelopment objectives linked to the participation of immigrants has 
not been raised to the same degree. The regional and local administrations have tended to focus more on co-development as a form of participation of immigrants and even on a destinationintegration approach, which has not been without problems and tensions. It is precisely one of these sub-state administrations, the regional government of Valencia (Generalitat Valenciana), which draws our attention on the following topics, in order to illustrate that the framework of relations between administration, immigrant associations and development organizations is subject to many tensions and contradictions.

\section{Discourse and Practice of Official Co-development in Valencia}

As Gómez Gil (2007) points out, 2005 could be considered the year of the emergence of co-development in the budgets of the regional and local cooperation in Spain. From that date, codevelopment has been a gaining presence in the regional plans for cooperation, integration and immigration, and different municipalities have established programs and provided funding in co-development. At the regional level, there are several communities that include references to co- development or make references to migratory flows in their cooperative laws (Balearic Islands, Murcia, or less explicitly Castilla-La Mancha). In contrast, other regions, such as Catalonia, Madrid, Basque Country, Aragon and Valencia even contemplate co-development within their respective master plans of cooperation for development.

The Valencian Autonomous Region Act Development Cooperation, adopted in 2007, introduced its own definition of codevelopment understood as an instrument of development cooperation under the following formulation: "It's about the set of transnational and inter-institutional actions aimed at promoting the involvement and active participation of the immigrant people with greater presence in the Valencian Community, in order to promote their potential as agents of development in their countries of origin, in coordination with other social organizations and local authorities. It includes, among other things, training, advice and technical assistance, as well as strengthening immigrant organizations and community origin; education and awareness of the Valencian 

cultural diversity are also included" (Law 6/2007 of 9 February, Development Cooperation of the Valencian Community).

This definition of the co-development proposal for a state government's sub- entity assumes, on the one hand, its increasing relocation on the agendas of non- central government departments (what might be called decentralization of co- development) and on the other hand, allows us to see the reorientation of codevelopment in the search for its social dimension and integration. At the same time, the exercise defining and providing innovations to co-development (to some extent), in Valencia, shows it is one of the pioneers in this field (something that the Valencian Government has been doing in recent years). Proof of this is the establishment in the year 2006 of the first specific call for co-development project funding or momentum in creating spaces and platforms for organizations in the areas of migration and co-development (the first creation of the Forum Immigration and, later, of the Federation of the International Co-Development and Cooperation, FEDACOD).

This priority given to co-development will be reinforced in the Master Plan 2008-2011, ${ }^{3}$ which introduces a significant shift by directly linking the development cooperation programs with integration of immigrants made by the Generalitat Valenciana, giving a boost to the co-development (Ibarra and Santander, 2012 , p. 70). From then the co-development will form part of the strategic priority policy lines of the Generalitat, in the field of development cooperation (through the Master Plan for Cooperation Valencia 2008-2011), as the scope of the integration of immigrants (through the Director of immigration and Coexistence Plan 2008-2011). As can be seen in Table 1, the co-development funds have increased substantially relative to other lines of cooperation subsidy by the Generalitat Valenciana, especially in 2011 and 2012, where in the midst of a drastic reduction of the other items intended for cooperation, co-development showed a much smaller decline, which made it possible to devote $44 \%$ of the total money of development cooperation.

${ }^{3}$ In the next Valencian Cooperation Plan Director (2014-2017) any reference to co-development or migration have been disappear. 
Table 1. Evolution of the different chapters of the Official Development Assistance (ODA) distributed in public calls by the Generalitat Valenciana and percentage dedicated to co-development

\begin{tabular}{lcclllll}
\hline Year & Development & $\begin{array}{l}\text { Sensibilizati } \\
\text { on }\end{array}$ & $\begin{array}{l}\text { Training } \\
\text { and } \\
\text { research }\end{array}$ & $\begin{array}{l}\text { Humanit } \\
\text { arian } \\
\text { action }\end{array}$ & $\begin{array}{l}\text { Co- } \\
\text { developm } \\
\text { ent }\end{array}$ & $\begin{array}{l}\text { Total } \\
\text { awaren } \\
\text { ess }\end{array}$ & $\begin{array}{l}\text { Percentage } \\
\text { dedicated to } \\
\text { co- } \\
\text { development }\end{array}$ \\
\hline 2006 & 10.963 .146 & 990.992 & 1.190 .880 & - & 1.308 .734 & 14.453 .732 & 9.55 \\
2007 & 14.735 .989 & 1.299 .991 & 1.802 .644 & - & 2.263 .848 & 20.102 .472 & 11.26 \\
2008 & 37.825 .043 & 3.919 .975 & 6.109 .929 & 4.090 .488 & 4.153 .137 & 56.098 .572 & 7.04 \\
2009 & 31.289 .159 & 2.766 .950 & 1.556 .678 & 2.171 .294 & 3.480 .677 & 41.264 .758 & 8.43 \\
2010 & 13.446 .678 & 2.296 .098 & 1.770 .688 & 2.448 .972 & 3.424 .033 & 23.386 .469 & 14.64 \\
2011 & 7.624 .561 & 1.171 .001 & 689.240 & 1.069 .362 & 3.051 .691 & 13.605 .855 & 22.42 \\
2012 & 1.375 .178 & 1.165 .300 & - & - & 2.305 .387 & 5.145 .300 & 44.80 \\
Total & 162.160 .935 & 17.400 .031 & 18.878 .057 & 9.780 .116 & 20.182 .120 & & \\
\hline
\end{tabular}

Source Compiled from the 2006-2012 resolutions calls. The data in the tables is limited to the period 2006-2012, starting and ending years of calls for projects of co- development. From the year 2012 there was reissued a call for that purpose 
However, this budget which benefits the co-development effort also hides troubling elements: first, the transfer of funds from development cooperation to the new chapter of co-development; second, the increased competition for resources between the different organizations involved in the field of co-development.

In this context, most of the funds for the co-development, as in the case with decentralized cooperation in general, will be received and administered mainly by the NGOs, and will be better positioned to meet their own criteria. In fact, the Partnership Act 2007 refers to the following actors: NGOs, Valencian universities, trade unions, enterprises and business organizations, but not to immigrant associations. ${ }^{4}$ Therefore, many of these associations will begin to make changes to their charters to access co-development funds, which is a major organizational change, accompanied by internal debates on whether or not this operation (between who see an opportunity in change and those who see in it the loss of the idiosyncrasies of the associations).

It is true, as Iborra and Santander (2012) say, that access to the calls for co- development has not been as restrictive as in the case of other criteria-although it is impossible to have a clear pattern of calls since the criteria have varied over the period 2006$2012^{5}$ - but it is undeniable that, in the majority of cases, those who have managed the funds of the calls have not been the associations of immigrants (they have not even been converted immigrant

\footnotetext{
${ }^{4}$ As specified in the Act 6/2007 of the Government and the Director of the Cooperation Plan 2008-2011 Valenciana are considered agents of international development cooperation in Valencia, institutions and entities that meet the following criteria: be an organization legal personality and legal capacity to act in accordance with current legislation in the field of international development cooperation; be non-profit; having registered office or permanent delegation in the Valencian Community; have among its purposes or express purpose, as shown in its statutes or equivalent, performing activities of international development cooperation and humanitarian action; have a structure capable enough to ensure the fulfillment of its objectives; the principles, objectives and performance criteria laid down in Chapter I of this Act.

${ }^{5}$ Also has been changing the geographical location of the projects, from the early years when it was limited to the 13 countries with the largest immigration in Valencia until 2012, where there is no limitation.
} 
associations in NGDOs) (Table 2). A detailed analysis of the successful bidders of the calls reveals that, to a greater extent, the NGOs and Foundations that were better positioned and had already been working in the field of development cooperation were awarded most of the projects and the largest amount of public funding.

So, as shown in Table 3 among the 10 states with the greatest number of projects funded by the calls for the years 20062012 are five foundations: three NGOs and two immigrant associations (the most prominent cases being those of ACSUD-Las Segovias NGOs and the Save the Children Foundation, who received grants for their projects in six of the seven calls, plus some of the highest amounts). The analysis of the figures allows us to speak beyond the official discourse on co-development and on the need to support and strengthen immigrant associations, a clearly unequal distribution of resources for the co-development between them and NGOs. This finding coincides with what St. Martin notes in his study of the city of Madrid, where he concludes that "it seems evident that there is a distance between the insistence on formal declarations, plans and projects, the relevance and the key role of migrants, and their effective recognition in the proceedings " (2011, p. 95).

In terms of strengthening associative, picked as a priority in the regional definition of co-development, one should also refer to the effects that access to calls for co-development has had on the associations of immigrants and the creation of partnerships with NGOs. Thus, both the Director of Immigration and Coexistence Plan 2008-2011, as well as the Director of the Valencia Cooperation Plan 2008-2011, establish as program goals the strengthening and revitalization of immigrant associations. The Master Plan for Cooperation itself goes even further and states that "a specific policy will be promoted in co-development, involving immigrants in the work of development of their countries of origin, including training and education, awareness and especially their participation in development projects and programs promoted by the Government, in coordination with the social cooperation of Valencia" (Generalitat Valenciana 2008, p. 9). In addition, "those programs and projects that incorporate immigrants living in the Valencian Region in the processes of identification, design, implementation and evaluation thereof will prevail; and, in particular, the participation of non-profit entities is valued and legally constituted to include, among its 
social purposes, care and support for immigrants" (Generalitat Valenciana 2008, p. 49).

Table 2. Approved projects and joint development projects submitted by immigrant associations

Year Number of projects Number of projects Total number of approved NGOs approved inmigrant projects approve associations

\begin{tabular}{lcll}
\hline 2006 & 11 & 1 & 12 \\
2007 & 11 & 1 & 12 \\
2008 & 15 & 4 & 19 \\
2009 & 15 & 1 & 16 \\
2010 & 10 & 2 & 12 \\
2011 & 14 & 8 & 22 \\
2012 & 7 & 3 & 10 \\
Total & 83 & 20 & 103 \\
\hline
\end{tabular}




\section{Source Compiled from the resolutions of the calls for co-development 2006-2012}

This approach, which in principle could make a positive reading, has also had its lights and shadows. While in some cases it has led to the progressive acquisition of autonomy for some immigrant associations against the NGOs, other associations have been relegated to an instrumental level within projects, when we have not considered their faults thoroughly. In this sense, one of the most successful cases of cooperation between NGOs and immigrant association has been the collaboration between the NGO ACSUDLas Segovia and The Association of Ecuadorian indigenous immigrants Intiñan. In this process, this association was strengthened not only organizationally in Spain through participation in various co-development projects, ${ }^{6}$ but also acquired a significant social and political involvement in the same country of origin through the creation of the Jatari Foundation (the Foundation works toward development in Saraguro, Ecuador). Instead, the case of collaboration between the NGO Association Valenciana Refugee Aid and the Association of Moroccan Immigrant of Tendrara (ASIMT) illustrates a different story, since the association of immigrants could grow through funded projects, but collapsed when the NGO entered an acute organizational and financial crisis. Another example of a different approach is the cooperation between the NGO CEAR Foundation and a group of associations of Moroccan immigrants in the Valencian Community (Transnational Net Valencia-Nador-Oujda), who sought to create a platform partnerships for co-development which was unsuccessful, mainly due to mistrust between the parties and the perception that the associations were only used for the purposes of the NGO.

These three examples highlight the opportunity represented for the co-development partnership between the NGOs present in the host society and immigrant associations, but also the risks of a partnership in which the participants are not placed at the same level or do not share the same goals.

\footnotetext{
${ }^{6}$ Having included as a partner in projects the NGO ACSUD-the Segovias calls for codevelopment in 2011 and 2012 the association of Indian immigrants saw Saraguros Intiñan first approved a draft submitted as applicant entity
} 
Table 3. Institutions with the highest number of co-development projects funded

Entity Number of projects

Foundation Save The Children $\quad 6$

ONGD ACSUD-Las Segovias 6

Foundation Ceimigra $\quad 5$

Foundation CEAR $\quad 5$

Foundation luve $\quad 5$

Association ACULCO 5

ONGD Jarit $\quad 5$

Foundation Agricultores Solidarios $\quad 4$

ONGD Assembly of Cooperation for Peace 4

Association AESCO 4

Source Compiled from the resolutions of the calls for co-development 2006-2012

We return to compare the above with the work of San Martín, who said "the model is that it seems more consolidated starring NGDOs, the projects they are working with, more public support and more robust infrastructure. Meanwhile, the associations remain weaker players, those who currently help in certain aspects of the project as an extra contribution to the NGO. We find, therefore, the work of voluntarism versus associative professionalized and structured NGOs, who today promote some projects that drive administration which previously competed in terms of inequality" (2011, pp. 94-95). In short, those who would have benefited to a greater extent include an industry tech with resources to attain the type of grants that require capabilities that immigrant associations usually do not have, something that is also true in the case of the Valencian Community.

\section{Immigrant Associations to Co-development as an Opportunity}

As we saw, while the original idea of co-development has as its 
main goal converting immigrant associations into genuine agents of transnational develop- ment, it is something easier said than done. To illustrate how co-development has representedborrowing Faist terminology-a space of opportunity that has not always produced the desired results, we present some significant results of two studies conducted in the Valencian Community. ${ }^{7}$ Our aim was to analyze what kind of migrant associations are taking actions that decide co-development and what their motivations are, while at the same time find out why others have chosen not to participate in official co-development schemes (see Table 4).

According to the investigation, the first significant result revealed that the co- development is actually a small part of the activity of immigrant associations (among all immigrant associations present in Valencia, only $16 \%$ of the total have been involved in activity related to co-development in recent years), although the latter was placed strongly in its own imagery and language, and is an area of future work for many of the these associations.

Also, in trying to reconstruct a profile of those immigrant associations that have seen in co-development an opportunity and have been active in this field, we can speak of 'prone to codevelopment' partnerships that share a number of common elements ${ }^{8}$ : organizations implemented at national and international level, with a wide range of institutional relations in both the host country and country of origin, while the sources of financing are government subsidies and grants. Furthermore, the association profile not involved in co-development is instead determined by existing local organizations whose institutional relations are specified and have limited space at the same establishment, and

\footnotetext{
${ }^{7}$ We base our analysis on seven paths of investigations in Valencia during the period 2009-2010, combining quantitative and qualitative fieldwork. For the quantitative part, a survey took place aimed at establishing the profile of immigrant associations in Valencia (the questionnaire was answered by 81 associations of a total sample of 220). For the qualitative part, interviews with 23 key informants of supportive organizations and immigrant associations were conducted.

${ }^{8}$ To do this, we used the analysis of multiple correspondence, taking into account whether the organization is involved in co-development project, its scope of implementation, the profile according to the degree of relationship with other institutions of the host country, the profile according to the degree of relationship with other institutions in the country and, finally, the profile according to the sources of funding. From the Cartesian diagram based on the relationship between the variables analyzed, we can distinguish which variables explain participation or not in the codevelopment.
} 
whose source of funding depends more on the rate of partners and activities throughout the year. In a second correspon- dence analysis, from the year of establishment of the organization and the funding source and the degree of participation in the action itself, we have seen how these variables are closely related to the type of co-development. The latter correspon- dence analysis allowed us to see several things: 1) the most recently created associations involved in co-development, created from 2006, especially set in motion aid actions that would be individually driven and financed from their own funds (as we shall see later, when discussing the creation of FEDACOD, this would agree with the profile willing partnerships that integrate the new platform entity); 2) associations with an intermediate length of existence, created between 2001 and 2005, have fundamentally linked their co-development projects to training, employment and social economy; 3) associations with longer life, created before 2001, have developed actions in a group with some NGOs, especially co- development projects related to microcredit.

Overall, the analysis reveals that the profile of immigrant associations involved in the field of co-development is entities with numerous partners, has implementation at national and international level, and possesses a good network of contacts with institutions both in countries of origin and destination. At the same time, they are more socially active, presenting a greater number of institutional relations with the public administration, as well as businesses and other organizations in civil society. However, even if they are organizations with numerous partners, the percentage share of the social base is also very low. In this regard, as noted by Masanet and Santacreu (2010), job insecurity and the limited availability of the immigrants' time makes participation limited in many cases by the members of the board.

On the other hand, and although most immigrant associations obtain funds through share partners, the organizations involved in co-development depend rather on aid and public subsidies, while "on many occasions maintenance and survival of the associations are subject to obtaining public funding" (Masanet and Santacreu 2010, p. 68). Likewise, if we take a closer look at the public licensee institution of such aid, we can observe that $90.9 \%$ of the associations involved in co- development activities obtain autonomic government funds, followed by the local (63.3\%) and 
state $(54.5 \%)$.

The dependence on public subsidies-especially those of regional origin-is remarkable. The risks that may be involved for immigrant associations are also important, and can be substantiated both in the economic and the political spheres. In the economic field the most obvious risk is, as we have seen, the effect of the crisis on the reduction of subsidies that has been recently produced, even with the disappearance of associations that could not support themselves financially. Politically, the risk is rather refocusing the agenda of the centrality of partnerships and projects and welfare activities to the detriment of the defense of the rights of immigrants.

In fact, for those immigrant associations that we can catalog as more "critical" of the official co-development system, their involvement in it would amount to a submission to the administration's own agenda without those immigrant associations having had the opportunity to take part in the system's preparation. For example, one of the organizations linked to the defense of the rights of immigrants in Valencia expressed its refusal to carry out projects of co-development funded with public money:

We have been interested in this issue for six years. We are interested, but there is a homogeneous view of all the board members and the intention or need to work on that line. The statute says that issues are new to us. Companions of our directors have participated in courses to design co-development projects, which we found interesting, and we are trying to do. But as we said, we know the government is best limited. That's why we came out; the fact is that we will make our own co-development regardless of these people or the government (Interview Ecuadorian Association Juan Montalvo).

The reasons for the estrangement of some immigrant associations are also extended to the reviews that have emerged regarding the ineffectiveness of international cooperation itself as well as the identification of co-development as a new variant of the latter. Perhaps for this reason, certain associations have initially preferred to continue their actions according to their own priorities and their own measures, without necessarily resorting to subsidies offered by the different administrations:

What we've worked for so slightly, is from the organization, funded 
by voluntary Contributions from partners. For example [...] was donated to the school bus in a town [...]. Children not attending school because, as they come down the mountain, they have to walk for two, or sometimes three, hours. This bus makes a journey that takes them to school and does not leave them at home alone because there are places in the house they are not permitted to enter. So this bus was donated from Rumiñahui. Like last year, when it gave shelter to a school [...] as needed...there had been heavy rains, and it was not able [...] But that is money from the partners (Interview Ecuadorian Association Rumiñahui).

Table 4. Immigrant associations with co-development projects funded Year Immigrant associations and their original countries

2006 ACULCO (Colombia)

2007 AESCO (Colombia)

2008 ACULCO (Colombia), AESCO (Colombia), Asociación SocioCultural Macodou Ssall (Senegal) 2009 Asociación Socio-Cultural Macodou Ssall (Senegal)

2010 ACULCO (Colombia), AESCO (Colombia)

2011 ACULCO (Colombia), Entreiguales (Colombia), Intiñán (Ecuador), Acolvalle (Colombia), Asociación Valenciana de Inmigrantes, AESCO (Colombia), Rumiñahui (Ecuador), ASOFLOES (Colombia)

2012 ACULCO (Colombia), Intiñán (Ecuador), Wafae (Marruecos)

Source Compiled from the resolutions of the calls for co-development 2006-2012

The result is that despite the opportunity it has represented, in the codevelopment in Valencia certain immigrant associations have preferred to stay out of new policies or are skeptical about them. This is something that has also been detected in other parts of Spain, as shown in the study of Ostergaard-Nielsen (2011) in 
Catalonia, where it is concluded that the general position of migrants is positive concerning the idea of their involvement in development projects in their hometowns; but they also raised skepticism concerning the ways of implementation of co-development. Immigrant associations investigated here think they are labeled as participants with no real ability to influence anything, while the development community is criticized for placing migrants in a development agenda that they have not built, without the ability to influence the political process that has set the parameters for their collaboration (2011, p. 32).

\section{From the Opportunities to the Risks of Cooptation in the FEDACOD Case}

The induced character of official co-development raises many questions about its effects on associations and practices. Codevelopment policies can provide an opportunity to strengthen immigrant associations by putting them under the spotlight of the authorities, but this is not guaranteed. The policy orientation by spurious interests can also generate risks to the organizations in terms of cooptation (Moctezuma 2011). In any case, the integration of official co-development schemes is not an aseptic operation, especially when these schemes have been conceived in a political context that seeks to achieve certain goals and includes organizations that can respond to them.

The case of co-development policy implemented in recent years in the Valencia Community shows the limits that have been identified for the policies of many countries in relation to the organizations of their citizens abroad (the case of Mexico, for example). Attempts to establish policies and design devices that try to frame the work of the organizations are not at all neutral. The formulation of certain policies not only has the effect of favoring certain kinds of actions, but also favors certain organizations that have lower resistance to the new proposals. The present case is of special interest, involving processes occurring in the country of destination of migrants and not in the country of origin, where these dynamics have received increased attention. It is often pointed out that the political culture of most developed countries is taken as a migration pull, and can act as a factor of change in organizational 
practices of migrants, giving them democratizing elements (mechanisms of election and representation, accountability accounts, transparency...). However, this is something that should not be assumed, without regard to the local context in which organizations take root and grow (the political ecosystem). The particular case of Valencia demonstrates that most of the risks identified regarding the policies of the state of origin in relation to organizations of the diaspora, means we can find them present here in their own policies designed in the context of reception.

Unlike what happened in the $90 \mathrm{~s}$, when in Valencia a small number of associations (the Association of Moroccan immigrants Al-Amal or association of Latin American immigrants ARI-Peru) had a prominent role in the mobilization of immigrants for their rights, together with other organizations such as the Bureau of Entities (Immigrant Solidarity) in recent years the advocacy work has moved into second place on the agenda of many of the new immigrant associations who have been devoted to codevelopment. For many of the newest associations, where partnerships have been created around new groups from Colombia, Ecuador and Romania, development organizations have also emerged from the same collective. Their growing public recognition without needing for it to be accompanied by greater advocacy capacity has been considered in itself an achievement in finding a space within the receiving society.

In this context, many of the associations have tended to stand as depoliticized organizations with a more technical background, focusing on project-based actions and attention, assistance, and largely relegating mobilization efforts, as seen in the previous section. However, as Fox and Gois remind us, that option is no longer just a political choice or, as they say, "the fact it prioritizes local projects in the short term is clearly a political decision" (2010, p. 115). On this issue, both authors write, concerning the Mexican case, that in advocacy on migration and development, there are differences of agenda between those focusing on trans-local projects and those who, on the other hand, focus on broader public policy. The first position can be characterized as more "pragmatic" and the second as more "political." A focus on projects involves a couple of advantages: the ability to produce tangible results in the short term with little risk of confrontation with the government of the country of origin. It also allows HTAs to be linked directly with 
local governments and communities on native soil. Instead, civil advocacy centered alternative develop- ment policies involve broader approaches, both in terms of scale and time, as well as less accurate possible links between reforms and their impact on certain sectors of the population in certain places" (Fox and Gois 2010, pp. 114-115).

The finding is that more "pragmatism" (referred to by Fox and Gois) is accompanied by the creation of new spaces of representation and participation, and has created new opportunities for certain immigrant associations, but also new risks. It would be the same risks that other studies have referred to concerning immigrant associations in Spain and their integration into platforms of political participation promoted by official proceedings, for example in the work of Toral (2010) and Veredas (2003) around clienteles and political risks of cooptation for immigrant associations from the creation of the Forum for the Social Integration of Immigrants, or Gonzalez and Morales (2006) on immigrant associations in Madrid. Along this line of investigation, the clearest example is perhaps that provided by Guillermo Toral in his study of immigrant associations represented at the Forum for the Social Integration of Immigrants-a body character state-who concludes that "in Spain, government intervention takes an overly large place in the field of immigrant organizations, at least in its current configuration. Corporatism that the political opportunity structure tends to cause in this country presents many dangers for the configuration of a strong civil society, because without a strong horizontal network and without an active participation of the members of the organizations' vertical integration organizations can serve to tame protests and claims of groups that are excluded from political citizenship" (Toral 2010, p. 126).

In this respect, one of the most controversial initiatives in the field of co- development in Valencia was the creation in 2010 of FEDACOD, composed mainly of new immigrant associations and development organizations which also have migrants in prominent positions $^{9}$ Regarding CONGDCV has currently 112 organizations within it. On both platforms only match two entities: Save The Children (an NGO) and ACULCO (an association of immigrants

\footnotetext{
${ }^{9}$ The Federation claims to have 115 member organizations, a list can be found at the following address: http://www.fedacod.org/index.php/acerca-de-fedacod/directorioentidades
} 
currently holds the presidency of FEDACOD).. For many NGOs that have been working for years in the field of development cooperation, the establishment of FEDACOD was interpreted as an attempt by the Valencian government of having a counterweight to its critical role, organized around the Coordinator NGOs in the Valencian Community, and increasingly distanced from the regional policies of cooperation for development implemented by the Ministry of Solidarity and Citizenship. ${ }^{10}$ The appearance of FEDACOD increased distrust of NGOs regarding immigrant associations and their instrumentalization through co-development agenda. ${ }^{11}$ The speeches of a number of NGOs refer to the "docility" of immigrant associations, and protest against the attitude of the first ones created.

However, the dividing line is not always so clear and does not necessarily involve the division between NGOs and immigrant associations, so that among the members of FEDACOD we can also find NGOs that do not necessarily have their origin in the middle of the migration, as among the organizations most critical of FEDACOD lie some of the first immigrant associations that were created in the Valencian Community. In this sense, we can say that the main differentiating variable between member organizations of FEDACOD and non-members does not seem to be the migrant component, but the temporal component: the older organizations (both migrants and non) have maintained their position of being critical, while more recently established organizations have adopted a more harmonious attitude toward regional policies, when they would not have been created precisely to align with these regional policies.

What is most obvious is that immigrant associations present in FEDACOD have made themselves more visible in the public space (although it does not necessarily mean that they have grown strong), but at the price of a challenge to their independence from

${ }^{10}$ During the last years of the Partido Popular in the Valencian Regional Ministry was headed by Rafael Blasco, who currently is judicially condemned, along with other senior officials for a possible diversion of funds from international cooperation.

11 The appearance of FEDACOD and co-development grants have also been addressed to the Valencian local press. See: www.levante-emv.com/comunitatvalenciana/.../799485.html 
Table 5. Entities belonging to FEDACOD codevelopment and grants received Entity FEDACOD Year (euros)

\begin{tabular}{|c|c|c|c|c|c|c|c|}
\hline & 2006 & 2007 & 2008 & 2009 & 2010 & 2011 & 2012 \\
\hline ACULCO & $\begin{array}{l}44.6 \\
14\end{array}$ & & $\begin{array}{l}135.1 \\
72\end{array}$ & & $\begin{array}{l}188.3 \\
25\end{array}$ & $\begin{array}{l}379.7 \\
65\end{array}$ & $\begin{array}{l}120.0 \\
00\end{array}$ \\
\hline $\begin{array}{l}\text { Agricultores } \\
\text { Solidarios }\end{array}$ & & $\begin{array}{l}106.8 \\
61\end{array}$ & & $\begin{array}{l}64.4 \\
42\end{array}$ & $\begin{array}{l}57.6 \\
25\end{array}$ & $\begin{array}{l}50.9 \\
81\end{array}$ & \\
\hline $\begin{array}{l}\text { Save The Children } \\
\text { Foundation IUVE } \\
\text { Coop. }\end{array}$ & $\begin{array}{l}103.8 \\
50\end{array}$ & 118.0 & $\begin{array}{l}125.9 \\
99.7 \\
36\end{array}$ & $\begin{array}{l}257.0 \\
120.7 \\
27\end{array}$ & $\begin{array}{l}244.8 \\
112.0 \\
97\end{array}$ & $\begin{array}{l}295.0 \\
78.6 \\
74\end{array}$ & 120.0 \\
\hline Sotermun & & & $\begin{array}{l}67.1 \\
80\end{array}$ & $\begin{array}{l}52.1 \\
20\end{array}$ & $\begin{array}{l}63.3 \\
34\end{array}$ & & \\
\hline ACOLVALLE & & & & & & $\begin{array}{l}22.8 \\
78\end{array}$ & \\
\hline $\begin{array}{l}\text { Foundation Proyecto } \\
\text { Senior }\end{array}$ & & & & & & $\begin{array}{l}19.5 \\
98\end{array}$ & \\
\hline ASOFLOES & & & & & & $\begin{array}{l}25.6 \\
00\end{array}$ & \\
\hline Valencian & & & & & & 24.4 & \\
\hline $\begin{array}{l}\text { Association of } \\
\text { Immigrants }\end{array}$ & & & & & & 00 & \\
\hline
\end{tabular}

Source Compiled from the resolutions of the calls for co-development 2006-2012

other organizations who have chosen not to join the new spaces of participation or who simply have not yet been invited to them. In this sense, competition for the leadership and resources in this new area has opened a gap in the world of social organizations and weakened the possibilities of presenting alternatives to policy officials, a fact that has also been detected in other studies, such 
as that of San Martín (2011, p. 88) on immigrant associations in the city of Madrid, which speaks of a painting competition and cooperation between actors driven by the government's agenda.

However, as we have seen above, most of the co-development project grants have been received by foundations and large NGOs not necessarily linked to FEDACOD. Anyway, in 2011, one year after the creation of the federation, we see a notable jump (see Table 5), and nine of the entities belonging to FEDACOD (among which are the association of Colombian immigrants ACULCO and Save The Children Foundation) received 896,899 euros of a total of $3,051,691$, equivalent to almost a third of the total. ${ }^{12}$ Similarly, in 2012, at a time when the number of subsidized projects was reduced considerably (from 20 in 2011 down to 10 in 2012), both entities-ACULCO and Save The Children-were again selected projects and the amounts received highest among all approved.

\section{Conclusions}

This article has addressed what were some of the main risks and opportunities that co-development policies have generated for immigrant associations, from the analysis of the case of Valencia in the last decade. Over recent years, many immigrant associations have joined the co-development language, and some have spoken in this new area, developing their own projects or working with development organizations. However, this new type of participation has also generated many questions and debates. The main criticisms have focused specifically on the role that government institutions have played in the implementation of new policies and related devices, as well as the type of relationship that would have been established between immigrant associations and administrations, on the one hand, and between the first associations and NGOs on the other.

As we have seen, co-development policies have arisen largely as a window of opportunity for immigrant associations, although the main beneficiaries would not have been the latter, but rather the foundations and NGOs. On the other hand, despite the possible

\footnotetext{
${ }^{12}$ In the call for 2011, a total of 22 organizations' projects were approved, of which 9 belong to FEDACOD
} 
"opportunity" that co-development represents, not all immigrant associations, nor NGOs, have known or wanted to take it. Some entities have been very critical, warning of the dangers of cooptation and loss of independence, while others have been left out by not having the skills and resources necessary to access the established channels. On the whole, co-development policies, at least in the case of Valencia, have created a scenario for which not all actors were ready, and some of them were yet to appear or be sufficiently strengthened.

The institutional framework for co-development created in Valencia has experienced many inconsistencies, including (and perhaps primarily) the fact that there is a protagonist-an organized migrant-who is not necessarily the beneficiary of the actions planned. On the other hand, the reduction of codevelopment devices to the formulation of the model based development cooperation projects tended to marginalize those initiatives that involve immigrant associations being made in a more informal way. The result is that we tend to consider as codevelopment those actions or projects that have been designed for concurrency in public calls (whether or not they were eventually funded), while many other activities at source are presented only as a commitment to their own communities.

The opportunity that co-development should have represented for immigrant associations has depended largely on the context in which it has been developing its work. For Valencia, the peculiarities of the political and institutional context in which it has developed co-development have not necessarily led to a strengthening of immigrant associations, although multiplication has occurred. In some cases, partnerships have been able to acquire increased resources or a greater role in some spaces of representation, but as has happened in other areas, this has not been accompanied by a real advocacy capacity. It seems instead that the aim has been to encourage partnerships as instances of representation, dialog and mediation between the immigrants themselves and administration by an extension of associations, but without the ability to set the political agenda. 
The recognition of migrants as agents of development has given these organizations some public prominence (some associations have grown considerably and have provided significant financial resources), but at the cost of modernization and the relegation of the more demanding part of their agendas. Policies that have tried to turn migrants into transnational actors have also caused the conversion of socio-cultural associations of immigrants into development associations, but without taking into account their capacity to take on this new challenge.

The character which largely induced co-development has also been supported in the configuration of a new associative framed representation in new platforms that have not given voice to immigrants but rather generated loyalty, according to the terminology of Hirschman (1977). Returning to the three possible responses for the inefficient behavior of institutions, we can conclude that the policies of co- development in Valencia have revolved more around ensuring loyalty (loyalties), while voice (voices) has been relegated to small associations located in the periphery of the institutional environment (exit). The potential enclosing the original idea of co-development, in terms of participation and a new transnational citizenship, has been diluted by attempts of political institutionalization. The result is that despite the novelty represented by co-development, it has been discredited in many areas and there is already great reluctance to use the same term between immigrant associations and development organizations.

\section{References}

Bayart, J. F. (2007). En finir avec le codéveloppement. Alternatives Economiques, 257, 26.

Cortés, A. (2006). Codesarrollo y Migración: Una Lógica Transnacional. Reflexiones desde el Caso Español, Puntos de Vista, 8, 7-27.

Cortés, A., \& San Martín, A. (2007). Política transnacional. Asociaciones migrantes y codesarrollo. El Viejo Topo, 239, 67- 
74.

Daum, C. (2008). Le codéveloppement, grandeur et décadence d'une aspiration généreuse. La revue internationale et stratégique, 68, 48-59.

Delgado, R., \& Márquez, H. (2007). Teoría y práctica de la relación dialéctica entre migración y desarrollo. Migración y Desarrollo, 9, 9-25.

Escala, L. (2005). Migración internacional y organizaciones de migrantes en regiones emergentes: el caso de Hidalgo. Migración y Desarrollo, 4, 66-88.

Faist, T. (2005). Espacio social transnacional y desarrollo. Una exploración de la relación entre comunidad, Estado y mercado. Migración y Desarrollo, 5, 2-34.

Faist, T. (2008). Migrants as transnational development agents: An inquiry into the newest round of the migration-development nexus. Population, Space and Place, 14, 21-42.

Fox, J., \& Gois, W. (2010). La sociedad civil migrante. Diez tesis para el debate. Migración y Desarrollo, 7(15), 81-218.

Giménez, C. (2004). Qué es el codesarrollo? Expectativas, concepciones y escenarios de futuro. Seminary Migraciones y desarrollo: Propuestas institucionales y experiencias prácticas. Madrid: CECOD.

Goldring, L. (2002). The Mexican state and transmigrant organizations: Negotiating the boundaries of membership and participation. Latin American Research Review, 37(3), 55-99.

Gómez Gil, C. (2008). Potencialidades y limitaciones del codesarrollo. Bilbao: Bakeaz.

Gómez Gil, C., \& González Parada, J. R. (2007). Las potencialidades del codesarrollo en la comunidad Valenciana. Musol, 2008. 
González Gutiérrez, C. (2006). Relaciones Estado-diáspora: aproximaciones desde cuatro continentes Tomo I. México: SREIME/Universidad Autónoma de Zacatecas/ANUIES/Miguel Á ngel Porrúa.

González, A., \& Morales, L. (2006). Las asociaciones de inmigrantes en Madrid. Una nota de investigación sobre su grado de integración política. Revista Españ ola del Tercer Sector, 4, 129-174.

Guarnizo, L. E. (1998). The rise of transnational social formations: Mexican and dominican state responses to transnational migration. Political Power and Social Theory, 12, 45-94.

Hirschman, A. O. (1977). Salida, voz y lealtad. Respuestas al deterioro de empresas, organizaciones y estados. México: Fondo de Cultura Económica.

Iborra, J., \& Santander, G. (2012). La cooperación para el desarrollo en la Comunitat Valenciana. Editorial 2015 y más, Madrid.

Lacomba, J., \& Boni, A. (2008). The Role of emigration in foreign aid policies: The case of Spain and Morocco. International Migration Journal, 46(1), 123-150.

Moctezuma, M. (2011). La transnacionalidad de los sujetos. Dimensiones, metodologías y prácticas convergentes de los migrantes mexicanos en Estados Unidos, Miguel Ángel Porrúa y Universidad Autónoma de México, México.

Ostergaard-Nielsen, E. (2011). Codevelopment and citizenship: The nexus between policies on local migrant incorporation and migrant transnational practices in Spain. Ethnic and Racial Studies, 34(1), 20-39.

Portes, A., Escobar, P., \& Walton, A. (2006). Organizaciones transnacionales de inmigrantes y desarrollo: un estudio comparativo. Migración y Desarrollo, 6, 3-44.

San Martín, A. (2011). Las asociaciones de inmigrantes en las actuaciones de codesarrollo: un estudio desde la ciudad de 
Madrid. Migraciones, 30, 71-99.

Toral, G. (2010). Las asociaciones de inmigrantes como sociedad civil: un análisis tridimensional. Revista Españ ola de Investigaciones Sociológicas, 132, 105-130.

Valenciana, Generalitat. (2008). Plan Director de la Cooperación Valenciana 2008-2011. Valencia: Consejería de Solidaridad y Ciudadanía.

Veredas, S. (2003). Las asociaciones de inmigrantes en España. Práctica clientelar y cooptación política, Revista Internacional de Sociología, 36, 207-225. 